\title{
Pengembangan Sistem Pembelajaran Berbasis Multimedia
}

\author{
Suryanto, Sunda Ariana \& Syahril Rizal \\ Universitas Bina Darma \\ Email:sur72nto@gmail.com
}

\begin{abstract}
Currently the development of information technology has an important influence in the development of learning systems, one of which is technology in the multimedia field. Multimedia technology is an indispensable tool for the learning process. The use of text, images, audio, video, and animation in learning helps students to quickly understand learning material. Multimedia also provides opportunities for educators to develop learning methods so that they get maximum results. AMIK AKMI Baturaja is a computer college that has not fully utilized information technology in its learning, especially in the field of Multimedia. For this reason, researchers conducted this research for the development of learning at the Campus AMIK AKMI Baturaja. This study aims to produce a multimedia-based learning media at AMIK AKMI Baturaja which can be a driving force for student learning achievement. In this study using a research method of literature study, observation, questionnaires, and interviews. The media development method uses MDLC (Multimedia Development Life Cycle) which consists of six stages, namely concept (needs analysis), design (design), material collecting, assembly, testing, and distribution. . The result of this research is a multimedia-based learning system presented in the form of e-learning. This media is expected to have a positive influence in increasing student achievement and learning independence.
\end{abstract}

Keywords: learning, MDLC, multimedia, e-learning, students

\section{Pendahuluan}

AMIK AKMI Baturaja adalah perguruan tinggi yang ada di Kota Baturaja Kabupaten Ogan Komering Ulu (OKU) provinsi Sumatera Selatan, yang memiliki dua jurusan yaitu Manajemen Informatika dan Teknik Informatika. Perguruan tinggi AMIK AKMI Baturaja memiliki 1100 mahasiswa aktif. Di AMIK AKMI Baturaja proses pembelajarannya belum sepenuhnya memanfaatkan Multimedia. Media yang digunakan berbentuk text book maupun download materi yang di upload oleh Dosen Pengajar di berbagai macam jejaring sosial, website dan blog yang tidak terletak pada satu sumber. Media pembelajaran adalah salah satu penunjang bagi Mahasiswa untuk lebih memahami materi dalam matakuliah guna meningkatkan prestasi belajar Mahasiswa.

Atas dasar itulah penulis melakukan penelitian pengembangan Sistem pembelajaran berbasis multimedia di AMIK AKMI Baturaja. Penulis melakukan penelitian untuk mengetahui apakah sistem yang sedang diterapkan sudah maksimal dalam mendukung prestasi belajar Mahasiswa, dan apakah sistem pembelajaran berbasis multimedia dapat membantu mahasiswa dalam memahami matakuliah yang disampaikan oleh dosen pengajar guna mendukung prestasi belajar Mahasiswa.

Data dari berbagai sumber nantinya akan menjadi dasar penulis dalam mengembangkan sistem pembelajaran berbasis multimedia. Penelitian ini akan berkaitan dengan Mahasiswa, perlengkapan peralatan pembelajaran, Dosen, dan perkembangan Teknologi Informasi yang di terapkan di Kampus AMIK AKMI Baturaja. Data tersebut merupakan masukan utama yang melatarbelakangi pengembangan sistem pembelajaran berbasis multimedia di AMIK AKMI Baturaja.

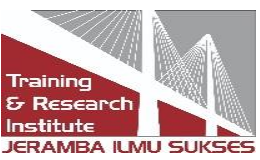




\section{Tinjauan Literatur}

Salah satu unsur yang sangat penting dalam peningkatan mutu pendidikan adalah peningkatan kualitas sumber daya manusia, baik tenaga pendidik maupun peserta didiknya. Sistem pembelajaran yang diterapkan dalam pengajaran, akan berpengaruh terhadap prestasi belajar peserta didik. Saat ini perkembangan teknologi informasi sangat berpengaruh penting dalam pengembangan sistem pembelajaran, salah satunya adalah teknologi dibidang multimedia. Teknologi multimedia telah menjanjikan potensi besar dalam merubah cara seseorang untuk belajar, untuk memperoleh informasi, dan memilih informasi. Multimedia juga memberikan peluang untuk pendidik guna mengembangkan metode pembelajaran, sehingga memperoleh hasil yang maksimal.

Hasil penelitian lembaga riset dan penerbitan komputer yaitu Computer Technology Research (CTR) juga menyatakan bahwa orang hanya mampu mengingat $20 \%$ dari yang dilihat, dan $30 \%$ dari yang didengar. Tetapi orang dapat mengingat $50 \%$ dari yang dilihat dan didengar, serta $80 \%$ dari yang dilihat, didengar, dan dilakukan sekaligus. (M. Suyanto, 2003:18). Sehingga dengan teori ini dapat dijadikan landasan dalam pengembangan sistem pembelajaran berbasis multimedia (Antoni, Akbar \& Fatoni, 2018; Antoni, Fikari, Akbar \& Jie, 2018; Akbar \& Antoni, 2019; Ariana, Azim \& Antoni, 2020; Antoni, Jie \& Abareshi, 2020).

\section{Metode Penelitian}

Penulis melakuan penelitian di kampus Akademi Manajemen dan Informatika AKMI Baturaja. Yang mempunyai 1100 Mahasiswa aktif. Kampus AMIK AKMI Baturaja terletak di Jl. Jend. A. Yani No. 0267 A Tanjung Baru Baturaja, Kabupaten Ogan Komering Ulu, Provinsi Sumatera Selatan.

Populasi dalam penelitian ini adalah semua Mahasiswa AMIK AKMI Baturaja. Sampel dalam penelitian ini dapat diambil dari jumlah populasi yaitu 1100 Mahasiswa dengan tingkat kesalahan 5\%, maka dari tabel Isaac dan Michael dapat ditentukan Jumlah sampel yang digunakan dalam penelitian ini adalah 265 Mahasiswa. Responden dalam penelitian ini adalah seluruh mahasiswa AMIK AKMI Baturaja dengan jumlah mahasiswa aktif sebanyak 1.100 Mahasiswa, dengan rincian sebagai berikut:

Tabel 1. Jumlah Populasi

\begin{tabular}{|c|l|c|c|c|c|c|}
\hline No & Jurusan & Semester 2 & Semester 4 & Semester 6 & $\begin{array}{c}\text { Jumlah } \\
\text { MI/TI }\end{array}$ & $\begin{array}{c}\text { Total } \\
\text { Mahasiswa }\end{array}$ \\
\hline 1 & $\begin{array}{l}\text { Manajemen } \\
\text { Informatika }\end{array}$ & 234 & 286 & 220 & 740 & \multirow{2}{*}{1.100} \\
\hline 2 & $\begin{array}{l}\text { Teknik } \\
\text { Informatika }\end{array}$ & 100 & 122 & 138 & 360 & \\
\hline $\begin{array}{l}\text { Jumlah Seluruh } \\
\text { Mahasiswa / Semester }\end{array}$ & 334 & 408 & 358 & \\
\hline
\end{tabular}

Teknik sampling yang digunakan dalam penelitian ini adalah Proportionate Stratified Random Sampling (Fauzi, Dencik \& Asiati, 2019). Penentuan sampelnya memperhatikan strata (tingkatan) yang ada dalam populasi. Dimana sampel yang akan diambil adalah mahasiswa 
semester awal sampai semester akhir. Dari tabel Isaac dan Michael didapat Total sampel 265, maka dapat dirincikan sebagai berikut:

Tabel 2. Rincian jumlah sampel

\begin{tabular}{|l|l|c|c|c|l|l|}
\hline $\begin{array}{l}\mathrm{N} \\
\mathrm{o}\end{array}$ & Jurusan & Smt. 2 & Smt. 4 & Smt. 6 & $\begin{array}{l}\text { Jumlah } \\
\text { MI/TI }\end{array}$ & $\begin{array}{l}\text { Total } \\
\text { Mahasiswa }\end{array}$ \\
\hline 1 & $\begin{array}{l}\text { Manajemen } \\
\text { Informatika }\end{array}$ & 56 & 69 & 53 & 178 & 265 \\
\hline 2 & $\begin{array}{l}\text { Teknik } \\
\text { Informatika }\end{array}$ & 24 & 30 & 33 & 87 & \\
\hline $\begin{array}{l}\text { Jumlah Seluruh } \\
\text { Mahasiswa } \\
\text { Semester }\end{array}$ & 80 & 99 & 86 & 265 & \\
\hline
\end{tabular}

Skala pengukuran dalam jawaban kuesioner yang dipakai pada penelitian ini adalah Skala Guttman, dimana jawaban akan didefinisikan terlebih dahulu, sehingga dapat menghasilkan sebuah jawaban yang berkualitas dan berarti. Skala Guttman ialah skala yang digunakan untuk jawaban yang bersifat jelas (tegas) dan konsisten.

Penggunaan skala ini ditujukan untuk melihat efektifitas sistem yang berjalan dan bentuk pengembangan sistem yang diinginkan atau cocok untuk diterapkan dalam perkembangannya

Metode pengumpulan data yang penulis pakai adalah Studi Literatur, Observasi, Kuesioner, Wawancara. Metode ini untuk mengetahui bagaimana efektivitas sistem yang berjalan guna pengembangan sistem yang sesuai dengan situasi, kondisi, dan perkembangan sistem sekarang.

Dalam penelitian ini penulis menggunaan metode MDLC (Multimedia Development Life Cycle). MDLC adalah metode pengembangan multimedia versi Luther-Sutopo. Metodologi pengembangan multimedia ini terdiri dari enam tahap, yaitu concept (pengonsepan), design (pendesainan), material collecting (pengumpulan materi), assembly (pembuatan), testing (pengujian), dan distribution (pendistribusian).

\section{Hasil dan Pembahasan}

Berdasarkan analisis data-data yang dikumpulkan, maka dapat dibangun sebuah perangkat lunak pembelajaran berupa e-learning, dengan menggunakan $\mathrm{cms}$ Moodle dengan tampilan sebagai berikut : 


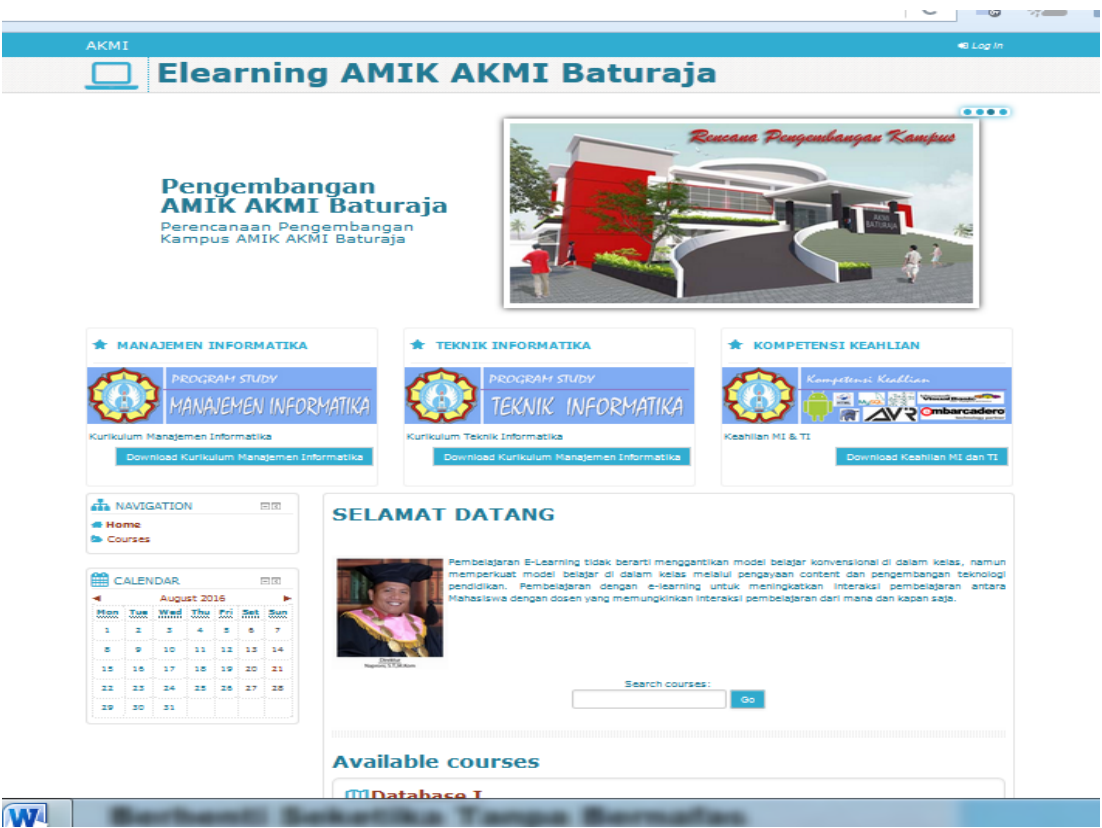

Gambar 1. Tampilan E-Learning AKMI

Adapun pembahasan dari proses pengembangan sistem dengan menggunakan metode pengembangan MDLC adalah sebagai berikut :

\subsection{Concept (Analisis Kebutuhan)}

Dari beberapa hal hasil dari penyebaran kuesioner, maka didapat beberapa hal kebutuhan sistem yaitu :

1. Sistem harus online, berbasis web.

2. Website dapat dijadikan tempat untuk download materi, mengulas materi, forum diskusi, pelaksanaan quis, mengumpul tugas dan terdapat tutorial pembelajarannya.

3. Website mampu menampung file text, gambar, audio, video dan animasi.

4. Sistem bisa dibuka oleh banyak orang dalam satu waktu.

5. Bisa terdapat banyak user yang mempunyai batasan-batasan tertentu.

\subsection{Design (Perancangan)}

Dari hasil analisis kebutuhan di atas, maka sistem akan dibuat adalah aplikasi online berupa website untuk E-Learning.

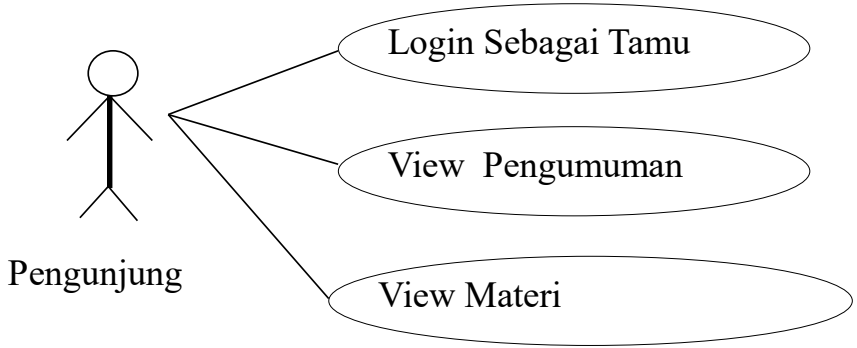

Gambar 2. Diagram use case pengunjung

Pada gambar 2 merupakan tampilan use case pengunjung, dimana pengunjung hanya dapat 
melakukan sedikit akses yaitu login sebagai pengunjung, melihat pengumuman, melihat mata kuliah.

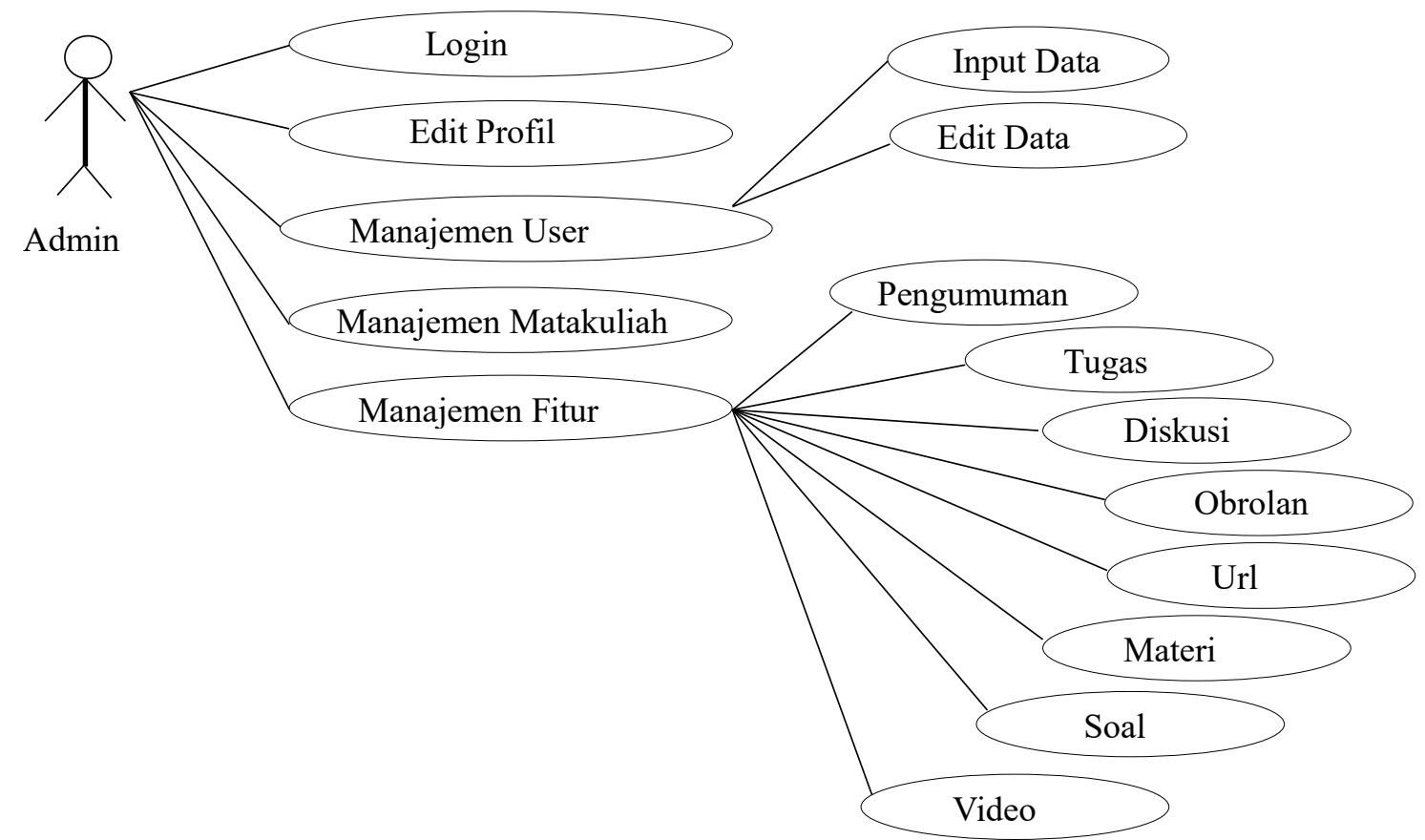

Gambar 3. Diagram use case Admin

Gambar di atas merupakan tampilan use case admin. Admin berperan sangat kompleks dalam memanajemen user, mata pelajaran dan fitur.

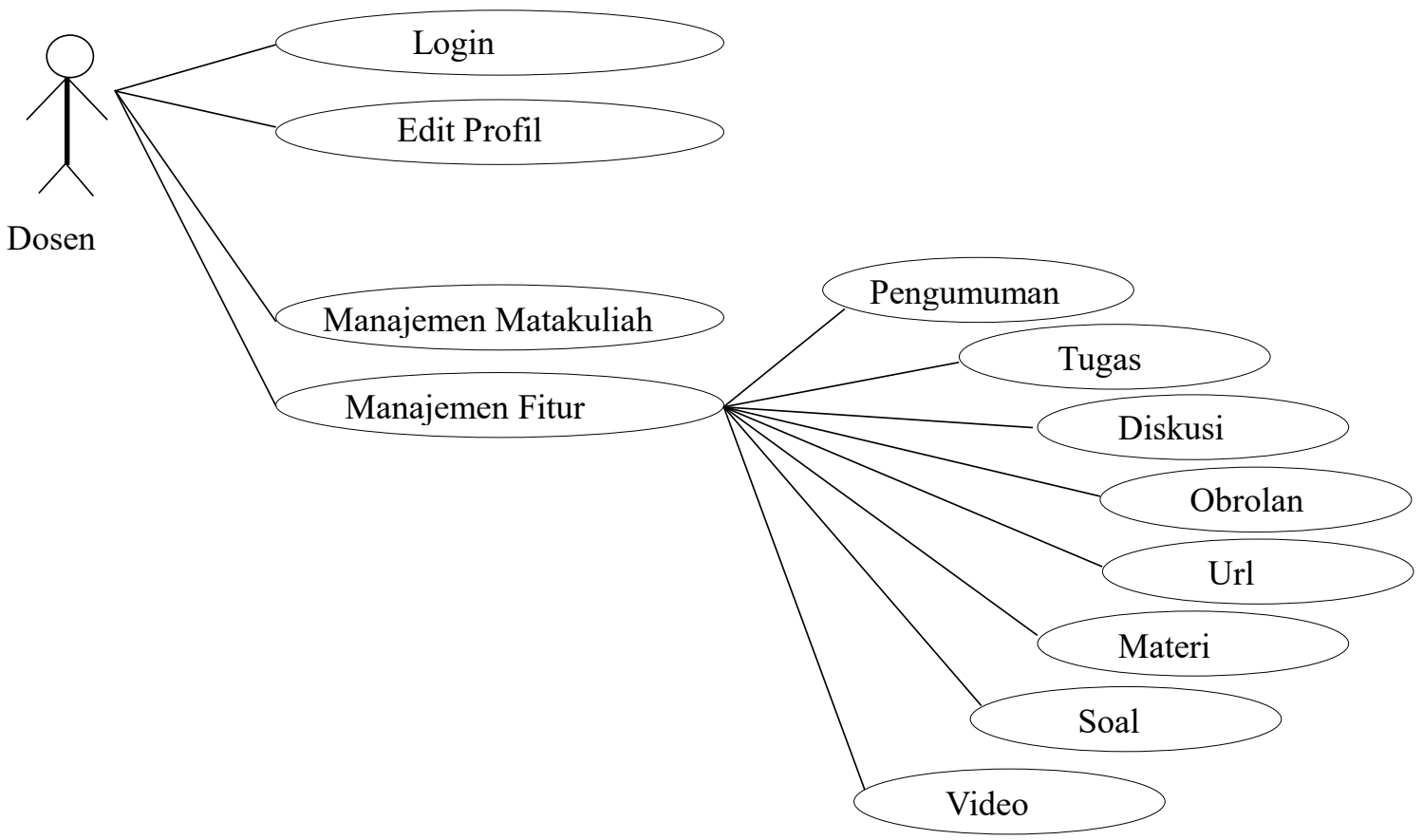

Gambar 4. Diagram use case Dosen 
Gambar di atas merupakan tampilan use case Dosen. Dosen hanya berperan memanajemen matakuliah dan fitur.

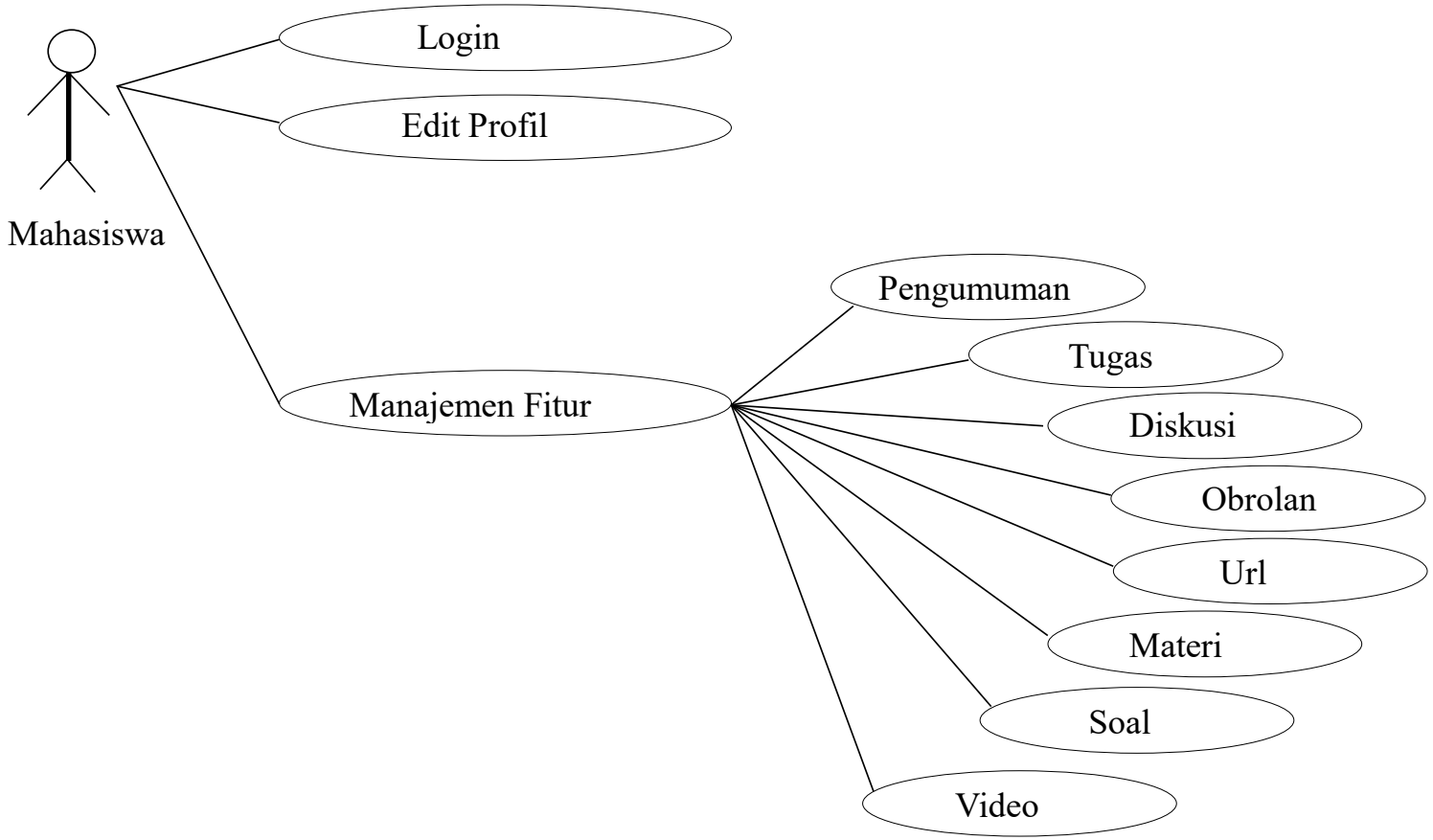

Gambar 5. Diagram use case Mahasiswa

Gambar di atas merupakan tampilan use case Mahasiswa, dimana Mahasiswa dapat melihat pengumuman, menerima tugas, melakukan diskusi, melakukan obrolan, membuka situs URL, download materi, mengerjakan soal, mengakses video.

\subsection{Material Collecting (Pengumpulan Materi)}

Materi atau bahan semua media pembelajaran diambil dari masing-masing PRODI di AMIK AKMI Baturaja yang berupa :

1. Data softcopy modul pembelajaran matakuliah

2. Tutorial pembelajaran semua matakuliah.

3. Soal-soal latihan, Soal-soal Ujian Tengah Semester, dan Soal-soal Ujian Akhir semester semua matakuliah.

\subsection{Assembly (Pembuatan)}

Melihat dari kebutuhan sistem di atas, disimpulkan bahwa sistem dapat dibangun dengan menggunakan Moodle. Moodle merupakan sebuah aplikasi Course Management System (CMS) yang gratis dapat di download, sehingga menekan biaya pengembangan sistem.

\subsection{Testing (Pengujian)}

Pengujian yang digunakan untuk menguji sistem yang baru adalah metode pengujian black box. Pengujian black box berfokus pada persyaratan fungsional perangkat lunak. Yaitu pengujian Alpha dan Betha.

\subsubsection{Pengujian Alpha}

Pengujian alpha dilakukan dengan menggunakan metode black box. Untuk pengujian alpha ini 
yaitu pada pengujian sebagai pengguna.

\section{Tabel 3. Pengujian Alpha}

\begin{tabular}{|c|c|c|}
\hline Item Uji & Detail Pengujian & Jenis Pengujian \\
\hline \multirow{3}{*}{ Login } & Verifikasi username & Black Box \\
\hline & Verifikasi password & Black Box \\
\hline & Verifikasi status & Black Box \\
\hline Pengolahan Data Admin & Edit Data Admin & Black Box \\
\hline \multirow[t]{4}{*}{ Pengolahan Data Dosen } & Tambah Data Dosen & Black Box \\
\hline & Edit data Dosen & Black Box \\
\hline & Cari data Dosen & Black Box \\
\hline & Hapus edit data Dosen & Black Box \\
\hline \multirow{4}{*}{ Pengolahan data Mahasiswa } & Tambah Data Mahasiswa & Black Box \\
\hline & Edit Data Mahasiswa & Black Box \\
\hline & Cari data Mahasiswa & Black Box \\
\hline & Hapus Data Mahasiswa & Black Box \\
\hline \multirow{3}{*}{ Pengolahan Data Kelas } & Tambah Data Kelas & Black Box \\
\hline & Edit Data Kelas & Black Box \\
\hline & Hapus Data Kelas & Black Box \\
\hline \multirow{3}{*}{ Pengolahan Data Mata Kuliah } & Tambah Data Mata Kuliah & Black Box \\
\hline & Edit Data Mata Kuliah & Black Box \\
\hline & Hapus Data Mata Kuliah & Black Box \\
\hline \multirow[t]{3}{*}{ Pengolahan Data Materi } & Tambah Data Materi Kuliah & Black Box \\
\hline & Edit Data Materi Kuliah & Black Box \\
\hline & Hapus Data Materi Kuliah & Black Box \\
\hline \multirow{3}{*}{ Pengolahan Data Mengajar } & Tambah Data Mengajar & Black Box \\
\hline & Edit Data Mengajar & Black Box \\
\hline & Hapus Data Mengajar & Black Box \\
\hline \multirow[t]{5}{*}{ Pengolahan Data Ujian } & Tambah Data Ujian & Black Box \\
\hline & Edit Data Ujian & Black Box \\
\hline & Hapus Data Ujian & Black Box \\
\hline & Pilih Peseta Ujian & Black Box \\
\hline & Lihat Nilai & Black Box \\
\hline \multirow[t]{5}{*}{ Pengolahan Data Tugas } & Tambah Data Tugas & Black Box \\
\hline & Edit Data Tugas & Black Box \\
\hline & Hapus Data Tugas & Black Box \\
\hline & Pilih Peseta Tugas & Black Box \\
\hline & Lihat Nilai & Black Box \\
\hline \multirow[t]{5}{*}{ Pengolahan Data Forum } & Lihat Data Forum & Black Box \\
\hline & Tambah Data Topik & Black Box \\
\hline & Hapus Data Topik & Black Box \\
\hline & Tambah Data Commen & Black Box \\
\hline & Hapus Data Comment & Black Box \\
\hline
\end{tabular}


Pengolahan Data Berita

\begin{tabular}{|l|l|}
\hline Lihat Data Berita & Black Box \\
\hline Tambah Data Berita & Black Box \\
\hline Lihat Data Berita & Black Box \\
\hline
\end{tabular}

\subsubsection{Pengujian Betha}

Kuesioner ini diajukan kepada 1 orang admin, 2 orang Dosen dan 7 orang Mahasiswa. Berikut ini adalah hasil prosentase masing-masing jawaban yang sudah dihitung nilainya dengan menggunakan rumus di atas.

Tabel 4. Hasil Kuesioner Pengujian Betha

\begin{tabular}{|c|c|c|c|c|c|c|c|c|}
\hline No & Pertanyaan & SS & $\mathrm{S}$ & $\mathrm{CS}$ & BS & $\mathrm{KS}$ & $\mathrm{TS}$ & STS \\
\hline 1. & $\begin{array}{l}\text { Apakah anda setuju bahwa Website } \\
\text { ini dapat menjadikan proses belajar } \\
\text { mengajar lebih optimal }\end{array}$ & $80 \%$ & $20 \%$ & & & & & \\
\hline 2. & $\begin{array}{l}\text { Apakah anda setuju bahwa dengan } \\
\text { Website ini Mahasiswa dapat dengan } \\
\text { mudah mendapat materi perkuliahan }\end{array}$ & $50 \%$ & $40 \%$ & $10 \%$ & & & & \\
\hline 3. & $\begin{array}{l}\text { Apakah anda setuju bahwa dengan } \\
\text { adanya website ini memudahkan } \\
\text { para Dosen untuk dapat } \\
\text { mendistribusikan materi perkuliahan }\end{array}$ & $70 \%$ & $20 \%$ & $10 \%$ & & & & \\
\hline 4. & $\begin{array}{l}\text { Apakah anda setuju bahwa website } \\
\text { ini membuka komunikasi antara } \\
\text { Dosen dan Mahasiswa ataupun antar } \\
\text { Mahasiswa di luar jam perkuliahan melalui } \\
\text { forum } \\
\text { diskusi dan private message }\end{array}$ & $50 \%$ & $40 \%$ & $10 \%$ & & & & \\
\hline 5. & $\begin{array}{l}\text { Apakah anda setuju bahwa dengan } \\
\text { website ini Mahasiswa akan menjadi lebih } \\
\text { aktif belajar menggunakan internet. }\end{array}$ & $70 \%$ & $30 \%$ & & & & & \\
\hline 6. & $\begin{array}{l}\text { Apakah anda setuju bahwa dengan } \\
\text { website ini Dosen dapat menemukan suatu } \\
\text { metode pengajaran yang lebih efektif }\end{array}$ & $60 \%$ & $40 \%$ & & & & & \\
\hline 7. & $\begin{array}{l}\text { Apakah anda setuju bahwa tampilan } \\
\text { website ini sudah cukup user friendly } \\
\text { untuk setiap } \\
\text { pengguna/pengunjung. }\end{array}$ & $50 \%$ & $30 \%$ & $20 \%$ & & & & \\
\hline 8. & $\begin{array}{l}\text { Apakah anda setuju jika website ini } \\
\text { sudah layak untuk di online kan }\end{array}$ & $60 \%$ & $40 \%$ & & & & & \\
\hline
\end{tabular}

Berdasarkan pengujian betha di atas, dapat dilihat bahwa pembangunan website E-Learning AMIK AKMI Baturaja ini :

1. Proses belajar mengajar menjadi lebih optimal.

2. Mahasiswa dapat dengan mudah mendapat materi perkuliahan. 
3. Memudahkan para Dosen untuk dapat mendistribusikan materi perkuliahan.

4. Membuka komunikasi antara Dosen dan Mahasiswa ataupun antar Mahasiswa di luar jam perkuliahan melalui forum diskusi.

5. Mahasiswa menjadi lebih aktif belajar menggunakan internet.

6. Dosen dapat menemukan suatu metode pengajaran yang lebih efektif.

\subsection{Distribution (Pendistribusian)}

Hasil dari pembuatan sistem dengan CMS Moodle di upload ke dalam hosting dan subdomain website AMIK AKMI Batuaja. Dengan alamat website sistem yang telah dibangun adalah http://elearning.akmi-baturaja.ac.id. Penggunanya yaitu Dosen dan Mahasiswa. Distribusi dilakukan dengan mengadakan sosialisasi dan pelatihan kepada para Dosen dan Mahasiswa serta menyebarkan alamat e-learning http://www.elearning. akmi- baturaja.ac.id ke group jejaring sosial dosen dan mahasiswa. Memberikan forum diskusi guna mendapat masukan dan memberikan penjelasan kepada pengguna terhadap sistem e-learning.

\section{Kesimpulan}

Dari hasil penelitian yang telah dirumuskan di atas, maka dapat disimpulkan bahwa :

1. Perangkat lunak pembelajaran yang diterapkan dalam pengembangan sistem pembelajaran berbasis multimedia di AMIK AKMI Baturaja dapat dikembangkan dengan menggunakan metode pengembangan MDLC (Multimedia Develoment Life Cycle). Berdasarkan metode tersebut, perangkat lunak dapat dibangun dengan menggunakan CMS Moodle, sehingga lebih menekan pembiayaan dalam pembuatannya. Yang menghasilkan sebuah E-learning dengan alamat http://www.elearning.akmi-baturaja.ac.id.

2. Kebutuhan sistem dapat diukur dengan mengumpulkan data-data tentang proses pembelajaran dan melakukan pengujian Alpha dan Betha setelah sistem dibangun agar dapat digunakan secara maksimal dalam proses pembelajaran. Dari pengujian Alpha, sistem dapat berjalan dengan baik tanpa adanya error. Dan dari pengujian Betha yang dilakukan, responden menyatakan bahwa : (a) 80\% Sangat setuju dan $20 \%$ Setuju bahwa website ini dapat menjadikan proses belajar mengajar lebih optimal; (b) 50\% Sangat setuju, 40\% Setuju, dan 10\% Cukup Setuju bahwa dengan website ini Mahasiswa dapat dengan mudah mendapat materi perkuliahan; (c) 70\% Sangat setuju, 20\% Setuju, dan 10\% Cukup Setuju bahwa dengan adanya website ini memudahkan para Dosen untuk dapat mendistribusikan materi perkuliahan; (d) 50\% Sangat setuju, 40\% Setuju, dan $10 \%$ bahwa website ini membuka komunikasi antara Dosen dan Mahasiswa ataupun antar Mahasiswa di luar jam perkuliahan melalui forum diskusi dan private message; (e) $70 \%$ Sangat setuju, $30 \%$ Setuju bahwa dengan website ini Mahasiswa akan menjadi lebih aktif belajar menggunakan internet; (f) 60\% Sangat setuju, 40\% Setuju bahwa dengan website ini Dosen dapat menemukan suatu metode pengajaran yang lebih efektif; (g) 50\% Sangat setuju, 30\% Setuju, dan $20 \%$ bahwa tampilan website ini sudah cukup user friendly untuk setiap pengguna/pengunjung; (h) 60\% Sangat setuju, 40\% Setuju website ini sudah layak untuk di online kan.

\section{Referensi}

Akbar, M., \& Antoni, D. (2019). E-supply chain management value concept for the palm oil industry. Jurnal Sistem Informasi, 15(2), 15-29.

Amalia, R. (2014). Membangun media pembelajaran interaktif berbasis web untuk anak 
bergaya belajar visual tingkat sekolah dasar. OAJIS.

Anisa, A. Z. (2014). E-Tung (edugame berhitung) sebagai media pembelajaran untuk anak Tk. Jurnal Telematika, 7(2).

Antoni, D., Akbar, M., \& Fatoni, F. (2018). Electronic government Rukun Tetangga model. Jurnal Sistem Informasi, 14(2), 64-73.

Antoni, D., Fikari, D., Akbar, M., \& Jie, F. (2018). The readiness of palm oil industry in enterprise resource planning. Telkomnika, 16(6).

Antoni, D., Jie, F., \& Abareshi, A. (2020). Critical factors in information technology capability for enhancing firm's environmental performance: Case of Indonesian ICT sector. International Journal of Agile Systems and Management, 13(2), 15-181.

Ariana, S., Azim, C., \& Antoni, D. (2020). Clustering of ICT human resources capacity in the implementation of E-government in expansion area: A case study from Pali regency. Cogent Business \& Management, 7(1), 1754103.

Eriyatno. (1999). Ilmu media: Meningkatkan mutu dan efektivitas manajemen. Bogor: IPB Press.

Fauzi, F., Dencik, A. B., \& Asiati, D. I. (2019). Metodologi Penelitian Untuk Manajemen dan Akuntansi. Jakarta: Salemba Empat.

Hasrul. (2010). Langkah-langkah pengembangan pembelajaran multimedia interaktif. Jurnal MEDTEK, 2(1).

Hidayatulah, A. H. (2014). Pengembangan bahan ajar berbasis web interaktif dengan aplikasi e-learning moodle pada pokok bahasan besaran dan satuan di SMA. Jurnal Pembelajaran Fisika, 4(2).

Lawanto, O. (2000). Pembelajaran berbasis web sebagai metoda komplemen kegiatan pendidikan dan pelatihan. Unitas, 9(1), 44-58.

Leacock, T. (2005). Building a Sustaniable e-Learning Development Culture. Bradfort.

Rohman. (2012). Media pembelajaran studio pinnacle berbasis multimedia. Journal SpeedSentra Penelitian Engineering dan Edukasi, 4(3).

Susanti, E. (2008). Rancang bangun aplikasi e-learning. Jurnal Teknologi, 1(1).

Suyanto, M. (2003). Multimedia alat untuk meningkatkan keunggulan bersaing. Yogyakarta: Andi.

Tasri, L. (2011). Pengembangan bahan ajar berbasis web. Jurnal MEDTEK, 3(2).

\section{Copyrights}

Copyright for this article is retained by the author(s), with first publication rights granted to the journal.

This is an open-access article distributed under the terms and conditions of the Creative Commons Attribution license (http://creativecommons.org/licenses/by/4.0/) 